\title{
POLITIK HUKUM BERDASARKAN KONSTITUSI
}

\author{
Danggur Konradus \\ Program Doktor Ilmu Hukum \\ Fakultas Hukum Universitas Diponegoro \\ Jalan Prof. Soedarto, SH, Tembalang Semarang \\ Email: konsdenggo21@gmail.com
}

\begin{abstract}
Every state had constitution. The constitution born of that state history self. UUD 1945 was borned through independence day on August 17 $7^{\text {th }}$ 1945. Formulation process of UUD 1945 that was done by Founding Fathers, it is far from partial, group and ethnic chauvinism thinking. They thought cosmosticly and find Indonesia nation personality crystallizing in Pancasila values that is inserted in UUD 1945's preamble as its fundament, why Indonesia state be formed. Socio-legal approach in post-positivism paradigm framework become reference of this article framework. Writer found that UUD 1945 wasn't only as law positive document but content nation soul also as moral reading and foundation of Indonesia law politic. Therefore law product is based on state constitution.
\end{abstract}

Keywords: Pancasila; UUD 1945; Law Politic of Indonesia

\begin{abstract}
Abstrak
Setiap Negara memiliki konstitusi. Konsitusi lahir dari sejarah bangsa itu sendiri. UUD 1945 lahir melalui Kemerdekaan 17 Agustus 1945. Perumusan UUD 1945 oleh pendiri Negara jauh dari pikiran parsial, kelompok dan sukuisme. Mereka berpikir secara kosmotik dan menemukan kepribadian bangsa Indonesia yang terkristal dalam nilai Pancasila termuat dalam pembukaan UUD 1945, sebagai landasan mengapa Negara Indonesia dibentuk. Pendekatan sosio-legal dengan kerangka paradigma post-postivisme menjadi pedoman kerangka penulisan ini. Penulis menemukan UUD 1945 tidak sekedar dokumen hukum tertulis, tetapi mengandung jiwa bangsa sebagai moral reading dan landasan politik hukum Negara Indonesia. Maka produk hukum mengacu pada konstitusi Negara.
\end{abstract}

Kata Kunci: Pancasila; UUD 1945; Politik Hukum Negara Indonesia

\section{A. Pendahuluan}

Berdasarkan etimologi, kata "konstitusi" berasal dari bahasa Perancis yaitu "constituer" artinya membentuk, menata, menyusun suatu negara. Bahasa Inggrisnya "constitution" yang berarti UndangUndangan Dasar (UUD). Kata “constitution"itu diterjemahkan menjadi UUD karena kebiasaan orang Belanda dan Jerman yang sehari-hari menggunakan kata "Grondwet" (grond: dasar; Wet: undangundang) dan "Grundgesetz" (grund: dasar; gesetz: undang-undang). Keduanya menunjukkan Undang-Undang Dasar sebagai naskah "tertulis". 1

Namun, L. J. Van Apeldoorn (dalam Miriam Budiardjo) membedakan makna "constitution" dan "Grondwet." Menurutnya, "Grondwet" adalah bagian tertulis dari suatu UUD, sedangkan "constitution" (UUD) memuat naskah tertulis dan unsur tidak tertulisnya. ${ }^{2}$

Dalam Black Law's Dictionary, "constitution" diartikan sebagai:

"The organic and fundamental law of nation or state, which may be written or unwritten, establishing the character and conception of its government, laying the basic principles to which its internal life is to be conformed, organizing government ....." (organik dan hukum fundamental sebuah

1. Miram Budiardjo, 2008, Dasar-Dasar Ilmu Politik, Edisi Revisi, Jakarta, Gramedia Pustaka Utama, hlm. 169

2. Ibid. 
bangsa atau negara, yang tertulis atau tidak tertulis, menentukan karakter dan konsepsi pemerintahannya, dan yang meletakan prinsip-prinsip dasar kehidupan internal Negara tersebut). ${ }^{3}$

Selanjutnya menurut Oxford Dictionary of Law "constitution" diartikan sebagai berikut:

"the rules and practices that determine the composition and functions of the organs of the central and local goveverment in a state and regulate the relationsionship between individual and the state(terjemahan: yang dinamakan konstitusi itu adalah tidak saja aturan yg trettulis tetapi apa yg dipraketekan dalam kegiatan penyelegaaaran negara dan yangdiatur itu tidak saja berkenanaan dengan organ negara beserta komposi dan fungsinya baik ditingkat pusat maupun ditingkat pemerintahan daerah, tetapi juga mekanisme hubungan antara negar atau organ negara itu dengan warganya negara.) ${ }^{4}$

Pertanyaan, apakah UUD 1945 (sebelum perubahan) memiliki kandungan makna yang lebih luas, dalam arti sebagai naskah tertulis dan memiliki unsur tidak tertulis seperti pendapat L.J. Van Apeldoorn? Untuk menjawab pertanyaan tersebut, perlu dikemukakan beberapa pendapat para ahli hukum tata Negara mengenai pengertian UUD. Pendapat mereka penting untuk memahami lebih dalam, misalnya mengapa negara yang baru berdiri harus memiliki konstitusi, kemudian mengubahnya sesuai dengan perkembangan zaman.

Menurut E.C. S. Wode (dalam Miriam Budiardjo), UUD adalah naskah yang memaparkan dan menentukan pokok-pokok dari badan pemerintahan suatu negara dan menentukan cara kerja badan tersebut atau dapat juga disebut UUD adalah dasar sistem peerintahan suatu negara. Selanjutnya Prof. Miriam Budiardjo menegaskan, bahwa UUD itu sebagai aturan hukum tertinggi yang mengikat semua warga dan lembaga negara tanpa pengecualian. Lebih lanjut dia mengemukakan ciri-ciri suatu UUD yaitu , membuat organisasi negara, hak asasi manusia dan prosedur mengubah UUD/Amandemen. Sementara itu, Muna Ndulo menyebutkan, bahwa UUD itu berisi mimpi masyarakat dan catatan perjalanan suatu bangsa yang majemuk, yang belum terselesaikan dan mengandung tujuan negara sebagai tujuan bersama sekaligus pembatas wewenang penyelenggara negara. Selengkapnya dia menyebutkan:

"Konstitusi suatu negara haruslah merupakan catatan kehidupan sebuah bangsa sekaligus mimpi yang belum terselesaikan. Konstitusi itu haruslah menjadi otobiografi nasional yang mencerminkan kemajemukan masyarakatnya. Harus menuliskan visi seluruh masyarakat dan dapat meyakinkan bahwa dalam konstitusi itu semua mimpi dan seluruh masyarakat tercapai." 5

Sedangkan Bagir Manan menyatakan, bahwa UUD 1945 sebagai Konstitusi sosial tidak semata-mata berisi aturan mengenai organisasi kekuasaan, melainkan meliputi pula aturan-aturan hak-hak rakyat dan kepentingan rakyat di luar politik yaitu kesejahteraan, kemakmuran dan keadilan sosial. Aturan-aturan yang tumbuh di luar Konstitusi merupakan sumber penting dan tidak mungkin diabaikan. ${ }^{6}$

Jimly Asshiddiqie menguraikan perspektifnya mengenai eksistensi konstitusi secara lebih luas dan selalu berbasis historis. Menurutnya konstitusi berasal dari sejarah Yunani kuno yang ketika itu disebut "politeia." Kemudian kata itu diadopsi ke dalam bahasa Latin dengan sebutan "constitutio." 7 "Constitutio" tersebut

3. Henry Campbell Black, M.A., 1975, Black's Law Dictionary, Fourth Edition, Washington DC, The Pbulisher's Editorial Staff,, p. 384.

4. Jimlly Assiddiqie, 2006, Pengantar Ilmu Hukum Tata Negara, Jilid I, Jakarta, Konstitusi Press, hlm 121-122

5. Numa Ndulo, 12 Januari 2011, Term Of.Reference Forum Group Discussion Re-Amandement, Bandung, Konstitusi

6. Nasional-Demokrat PSKN FH Unpad, hlm.1.

6. Bagir Manan \& Harijanti Dwi Susi, 2014, Memahami Konstitusai Makna dan aktualisasi, Cet. Ke 1, Jakarta, PT.Raja

7. Grafindo Persada, hlm 39.

7. Jimly Assiddiqie, Op.cit., hlm 89-91. 
kemudian dihubungkan atau dikaitkan dengan kata "jus" atau "ius" yang berarti hukum atau prinsip. Zaman Yunani pengertian "constitution" masih bersifat materil, belum berbentuk konstitusi seperti pada zaman moderen. Jimly mengutip pendapat Prof. Djoko Sutono dan mengatakan konsep "konstitusi" mengandung 3 (tiga) pengertian yaitu (a) konstitusi dalam arti materil; (b) konstitusi dalam arti formal; dan (c) konstitusi dalam arti yang didokumentasikan untuk kepentingan pembuktian dan kesatuan rujukan. ${ }^{9}$

Berdasarkan pendapat para pakar di atas, konstitusi dapat dimaknai sebagai UUD suatu negara, dasar hukum berdirinya suatu negara dan konsep dasar membangun sebuah negara. Atau apa yang disebut oleh K.C. Wheare bahwa konstitusi merupakan "resultante", yaitu kesepakatan politik lembaga yang membuatnya sesuai dengan keadaan sosial, politik dan ekonomi pada saat konstitusi tersebut dibuat. ${ }^{10}$ Di Indonesia misalnya, terjadi perubahan sosial politik dan ekonomi sebagai efek domino gerakan reformasi yang dipelopori mahasiswa tahun 1998. Kondisi sosial tersebut berdampak pula pada perubahan UUD sehingga UUD 1945 dilakukan amandemen sebanyak empat kali. Konstitusi itu tidak saja dipandang sebagai naskah hukum yang berisikan dasar-dasar pemikiran, norma-norma, kaidah-kaidah penuntun baik tertulis maupun tidak tertulis, tetapi juga mengandung jiwa bangsa untuk mengatur jalannya penyelenggaraan negara. Dengan perkataan lain Konstitusi merupakan ekspresi kosmologis dan cita-cita bangsa serta landasan filosofis mengenai orientasi dan tujuan kemana negara itu dibawa. Aturan dasar negara dengan segenap politik hukumnya, harus disandarkan kembali secara konsisten pada konstitusi. ${ }^{11}$

Sehubungan dengan pertanyaan sebelumnya, yaitu apakah UUD 1945 sebagai Konstitusi mengandung naskah tertulis dan unsur tidak tertulis? Terhadap pertanyaan tersebut, Miriam Budiardjo mengatakan, bahwa pembuat UUD 1945 menganut pemikiran yang sama dengan pemikiran L.J. Van Apeldoorn di atas sebagaimana tertulis di dalam penjelasan UUD $1945^{12}$ (praamandemen). Dengan mencermati Pembukaan UUD 1945 alinea ke IV, cukup jelas bagi kita, bahwa UUD 1945 adalah Konstitusi Negara Republik Indonesia yang mengandung hukum dasar tertulis dan hukum dasar tidak tertulis serta mengandung ekspresi kosmologi bangsa, cita-cita dan landasan filosofis mengenai orientasi dan tujuan negara. Dengan demikian, pemahaman terhadap konstitusi sebuah Negara merupakan mekanisme penting untuk memahami alasan dibentuknya sebuah Negara, memahami ideologi, filosofi, tujuan dan politik hukum sebuah Negara. Berdasarkan latar belakang tersebut, maka penulis tertarik untuk membahas mengenai bagaimana politik hukum Indonesia berdasarkan konstitusi, baik sebelum maupun sesudah amandemen?

\section{B. Pembahasan}

Konstitusi negara manapun di dunia, tidak terlepas dari sejarah terbentuknya negara tersebut. Eksistensinya mewakili perasaan-perasaan tertentu, sebagai piagam pergulatan manusia dan sebagai dokumen hukum suatu negara. Konstitusi bukan regulasi atau peraturan (wet/UU) melainkan "kaidah yang berisi pesan-pesan moral sehingga membacanya sebagai "moral reading" (Ronald Dworkin: 1996). ${ }^{13}$

Konstitusi tidak hadir begitu saja, tetapi kehadirannya sebagai ekspresi pergumulan sebuah bangsa mengenai nilai-nilai budaya, kaidah-kaidah, filosofi dan tujuan pembangunan bangsa tersebut. Konstitusi Negara Indonesia misalnya menjadi landasan pijak bagi arah politik hukumnya.

8. Solly Lubis, 1983, Asas-asas hukum Tatanegara, Cet.ke-2, Bandung, Alumni, hlm. 44

9. Ibid.

10. Mahfud MD, 2010, Politik Hukum di Indonesia, Jakarta, Rajagrafindo, hlm 10

11. Martha Pigome, "Implementasi Prinsip Demokrasi dan Nomokrasi dalam Struktur Ketatanegaraan RI Pasca Amandemen UUD 1945”, Jurnal Dinamika Hukum, Vol 11, No. 2, Mei 2011, hlm 11

12. Miriam Budiardjo Op.cit, hlm.1

13. Satjipto Rahardjo, 2007, Mendudukan Undang-Undang Dasar, Suatu Pembahasan Dari Optik Ilmu Hukum Umum, cet. I, Semarang, Badan Penerbit Universitas Diponegoro, hlm. 8-11 dan hlm. 34 
Berlandaskan pada rumusan tersebut, muncul pertanyaan, apa itu politik hukum? Menurut Mahfud MD, politik hukum adalah legal policy atau garis kebijakan resmi dan sah tentang hukum yang akan diberlakukan baik dengan pembuatan hukum baru maupun dengan pergantian hukum lama dalam rangka mencapai tujuan negara. ${ }^{14}$

Rumusan politik hukum Mahfud MD di atas memiliki persamaan secara substantif dengan formulasi politik hukum yang dikemukan oleh Padmo Wahjono yang mengatakan, bahwa politik hukum adalah kebijakan dasar yang menentukan arah, bentuk maupun isi hukum yang akan dibentuk. Berdasarkan pengertian sebagaimana telah diuraikan di atas, dapat dimengerti bahwa Konstitusi dan politik hukum Indonesia dapat dipahami dari beberapa peristiwa sejarah yang penting berkaitan dengan pembentukan konstitusi (UUD 1945) dan politik hukumnya serta perubahan konstitusi tersebut yang kerap kali dimengerti seiring dan seirama dengan perkembangan dan perubahan zaman. Karena itu dalam tulisan ini politik hukum dalam konteks Indonesia, dibagi dua bagian yaitu politik hukum sebelum amandemen UUD 1945 dan pasca amandemen UUD 1945. Kedua peristiwa penting ini memiliki implikasi terhadap produk hukum negara Indonesia.

\section{Sebelum Amandemen UUD 1945}

Pada bagian ini, penulis memulai dengan satu pertanyaan, apakah UUD 1945 hasil produk politik hukum dan bagaimana implikasinya terhadap produk hukum yang ada? Sebagaimana diketahui, bahwa yang menetapkan UUD 1945 adalah PPKI, yang diketuai oleh Soekarno. Badan ini untuk pertama kalinya memilih Presiden dan Wakil Presiden sebagaimana disebutkan dalam Pasal III Aturan Peralihan, karena lembaga DPR belum terbentuk. Karena itulah maka pada awal kemerdekaan, kekuasaan Negara sepenuhnya berada pada Presiden dan dibantu oleh Komite Nasional, sebagaimana disebutkan dalam Pasal IV Aturan Peralihan

\section{UUD 1945.}

Kemudian UUD 1945 yang ditetapkan itu dinyatakan bersifat sementara, karena itu disebut tidak sempurna, yang artinya normanorma yang terkandung didalamnya bersifat sementara dan disempurnakan di kemudian hari. Hal ini terungkap dari Pidato Soekarno sebagai ketua PPKI yang mengatakan:

"UUD yang dibuat sekarang adalah Undang-Undang Dasar sementara. Kalau boleh saya memakai perkataan ini adalah UUD kilat. Nanti kalau kita telah bernegara di dalam suasana yang lebih tentram, kita tentu akan mengumpulkan kembali MPR yang dapat membuat Undang-undang yang lebih lengkap dan sempurna......"

$\mathrm{S}$ e b a g a p e n u t un a w a 1 terselenggaranya pemerintahan negara yang baru merdeka, atau landasan konstitusional penyelenggaraan pemerintahan Negara, tentu saja UUD 1945 merupakan produk politik hukum. Itulah sebabnya, politik hukum menghasilkan Konstitusi. Instrumen operasionalisasi dari ketentuan konstitusi tersebut adalah undang-undang. Lalu UU yang diterbitkan itu terdiri dari UU yang dibuat atas dasar perintah langsung UUD dan UU yang dibuat di luar perintah langsung UUD ${ }^{15}$ Prinsipnya bahwa UU dibuat tidak terlepas dari fakta empiris dalam kehidupan masyarakat berupa kerupa kebutuhan riil akan tata tertib dalam masyarakat. Melalui UU masyarakat diatur ketertibannya, sehingga terciptalah harmonisasi dalam kehidupan sosial. Selain itu adanya produk hukum tersebut, maka terciptalah proses kodifikasi norma-norma dan tata nilai termasuk terciptanya modifikasi dalam masyarakat. ${ }^{16}$

Politik hukum untuk memecahkan masalah kekosongan hukum setelah kemerdekaan, dan selama masa transisi pemerintahan dari pemerintahan Belanda kepada pemerintahan Indonesia, pemerintah Indonesia memberlakukan ketentuan Pasal II Aturan Peralihan sebagai landasan hukum untuk tetap memberlakukan peraturan hukum warisan pemerintahan kolonial, dan setelah

\footnotetext{
14. Mafud MD, Op.cit, hlm.1.

15. Mahfud MD, 2012, Pengantar Buku, Pataniara Siahaan, Politik Hukum Pembentukan UU Pasca Amandemen UUD 16. 1945 id. 1945, Jakarta, Konpress, hlm. XIV
} 
70 tahun Indonesia merdeka, aturan hukum warisan kolonial tersebut masih berlaku.

Pada periode berikutnya, UUD 1945 mengalami perubahan, dari UUD 1945 menjadi UUD RIS yang berlaku dari tanggal 27 Desember 1949 sampai dengan 17 Agustus 1950. Perubahan konstitusi berdampak pada perubahan bentuk Negara, yang semula berbentuk Negara Kesatuan Republik Indonesia berubah menjadi Negara Republik Indonesia Serikat (RIS) di bawah UUD RIS yang berlaku hanya satu tahun. Setelah Negara RIS bubar maka berlakulah UUDS (Undang-Undang Dasar Sementara) yang berlaku sejak tahun 1950-1959. Lalu pemberlakuan UUDS dihentikan oleh pemerintah dan pemerintah kembali ke UUD 1945 sebagai konstitusi yang sah melalui Dekrit Presiden Soekarno 5 Juli 1959. Pada zaman bung karno konsitusi kental dengan nuansa demokrasi politik dan demokrasi ekonomi yang sering disebut juga sebagai socio-demokrasi. ${ }^{17}$ Karena itu politik hukum nasional mengalami perjalanan sangat panjang, sejalan dengan konfigurasi politik meliputi perjalanannya sampai diamandemen tahun 2002. Dalam perjalanan politik mulai dari pergantian regim Orde Baru maupun Orde Lama, politik hukum nasional berasaskan pada hukum tertulis tanpa partisipasi masyarakat. Bahkan pengaruh politik lebih dominan terhadap hukum yang implikasinya, hukum menjadi tidak demokratis. ${ }^{18}$ Ketidak-demokratisan tersebut disebabkan karena kekuasaan yang membuat Rancangan Undang-Undang (RUU) di bawah kekuasaan Presiden dan DPR hanya menyetujui kehendak Presiden. Sehingga rakyat mencap DPR di bawah regim Orde Baru adalah lembaga tukang menyetujui dan tukang stempel UU yang dibuat pemerintah. ${ }^{19}$

Politik hukum regim Orde Baru dirumuskan di dalam Garis Besar Haluan Negara (GBHN), melalui politik pembangunan yang dikenal dengan nama Rencana Pembangunan Lima Tahun Pertama (REPELITA I). Konsep REPELITA dirumuskan secara sistematis dalam GBHN yang disahkan perberlakuannya melalui Ketetapan Majelis Permusyawaratan Rakyat(TAP MPR). Di dalam GBHN politik hukum merupakan bagian dari kebijakan strategis pemerintah yang dikenal dengan sebutan "arah kebijakan politik bidang hukum”. Ketetapan-ketetapan MPR yang meletakkan dasar arah kebijaksanaan politik bidang hukum tersebut adalah TAP. MPR N o.I V/MPR/ 1973; T A P . M P R No.IV/MPR/1978; TAP MPR No. II/MPR/ 1983; TAP MPR No.II/MPR/1988; TAP. MPR No.II/MPR/ 1993 dan TAP MPR No.X/MPR/ 1998. Namun walaupun arah politik bidang hukum tersebut dengan jelas dirumuskan di dalam GBHN, tetapi arah kebijakan tersebut tetap melahirkan UU yang tidak demokratis. Misalnya, Undang-Undang Pemerintahan Desa yang cenderung menghapus komunitas-komunitas tradisional.

Pembukaan dan Batang Tubuh UUD 1945 adalah sumber keseluruhan politik hukum nasional yang diterjemahkan dan diimplementasikan oleh Orde Baru melalui arah kebijakan politik bidang hukum dalam GBHN. Penetapan Pembukaan dan Batang Tubuh UUD 1945 sebagai landasan politik hukum nasional, setidaknya didukung oleh dua argumentasi rasional. Pertama, memuat tujuan, cita-cita hukum dan norma dasar negara Indonesia. Kedua, mengandung nilai luhur warisan nenek moyang Indonesia yang telah terkristalisasi dalam falsafah Pancasila, yang mana hukumnya adalah hukum Pancasila yang kalau dikombinasikan dengan nilai sosial menghasilkan nilai pilihan yang oleh F.W Riggs disebut nilai primastik yang dalam konteks hukum dinamakan "hukum prismatik" ${ }^{20}$ Model hukum prismatik inilah yang akan dikembangkan secara terusmenerus bagi pembangunan politik hukum pasca-amandemen UUD 1945, karena DPR mempunyai kekuasaan yang sangat kuat untuk membuat RUU. Sehubungan dengan ini, sumber daya manusia (SDM) DPR menjadi titik penentu dalam merumuskan nilai dan norma yang menjadi materi muatan

\footnotetext{
17. Djauhari, “Konsep Negara Kesejahteraan Pra Kemerdekaan RI”, Jurnal Hukum FH Unissula, Semarang, Vol. 16, No. 2, Juni 2006, hlm 23.

18. Mr. Roeslan Saleh, Materi Kuliah Sejarah Hukum Indonesia, Pasca Sarjana UNKRIS, 1999,

19. Sardjono Djatiman, Kuliah Sosiologi Hukum, Pasca Sarjana UNKRIS, September 1999,

20. Mahfud MD, 2012, Op.cit, hlm 23
} 
UU yang dihasilkannya.

\section{Politik Hukum Pasca- Amandemen UUD 1945}

Perubahan UUD 1945 (empat kali amandemen) yang kini menjadi UUD Negara Republik Indonesia Tahun 1945 membawa implikasi luas, tidak saja di bidang legislasi dan ketatanegaraan, tetapi juga sistem hukum nasional. Terjadi pergeseran kekuasaan pembuat UU dari kekuasaan Presiden (Eksekutif) menjadi wewenang yang berada di tangan DPR (Yudikatif) . Sebelumnya posisi Presiden lebih kuat dari pada DPR dalam pembentukan UU, sehingga DPR sebagai pemegang kekuasaan legislasi sifatnya semu (Sadli Isra: 2011). Pergeseran sistem legislasi pasca- amandemen UUD 1945 membuat DPR memposisikan dirinya sebagai lembaga Negara yang kuat untuk membentuk UU. Karena itu DPR berperan aktif dalam mengajukan RUU sebagai konsekuensi politik atas hak konstitusionalnyaitu.

Atas dasar itu, perubahan UUD 1945 tidak terlepas dari kondisi obyektif Indonesia, yaitu kondisi politik, ekonomi, sosial dan budaya yang semuanya berubah mengikuti perkembangan zaman. Faktor lainnya adalah adalah karena UUD 1945 itu sebagai konstitusi tidak lagi berjalan sesuai dengan "staatside" 21 sebuah negara yang berdasarkan konstitusi yang mengharuskan tegaknya tatanan demokrasi, negara berdasarkan atas hukum, menjamin tegaknya hak asasi manusia (HAM), terciptanya kekuasaan kehakiman yang merdeka demi tegaknya keadilan sosial dan terkuburnya kekuasaan otoriter. Hal-hal itu membawa kita ke dalam pemahaman bahwa adaptasi ketentuan hukum dengan perkembangan masyarakat dalam berbagai aspek kehidupan sosial akan mengakselerasi perubahan kearah terwujudnya kesejahteraan dan keadilan sosial.

Desakan perubahan UUD 1945 bukan baru dilakukan tahun 2002, tetapi sudah sejak tahun $1999^{22}$ Slamet Efendy Yusuf dan Umar Basalim misalnya, mengemukakan enam alasan perlunya perubahan UUD 1945, yaitu antara lain: Alasan filosofis, sosiologis, historis, yuridis dan praktek ketatanegaran serta materi UUD 1945. Alasan historis, terkait dengan "sifat kesementaraan UUD 1945" sebagaimana yang sudah diungkapkan sebelumnya. Alasan "sementara"dapat diasumsikan bahwa kondisi obyektif ketika merumuskan materi UUD 1945 itu dalam situasi negara Indonesia yang baru merdeka dan kemudian diikuti dengan peralihan kekuasaan, juga peperangan Asia Timur Raya yang kesemuanya memberi pengaruh tidak langsung kepada perumus UUD 1945.

Sejalan dengan pendapat Efendy Yusuf dan Umar Basalim di atas, Mahfud MD, menyampaikan empat kelemahan mendasar UUD 1945 yang dapat menjadi pintu masuk bagi pemerintahan otoriter sehingga konstitusi tersebut perlu diubah. Kelemahankelemahan tersebut adalah (a) tidak adanya mekanisme "check and balances"; (b) terlalu banyak atribusi kewenangan kepada lembaga legislatif untuk membentuk UU; (c) adanya pasal-pasal multi tafsir; dan (d) terlalu percaya pada semangat penyelenggara negara.

Sejalan dengan ditetapkannya UUD Negara Republik Indonesia Tahun 1945, hal menonjol sebagai kemajuan dari perubahan UUD tersebut adalah tersistematisnya rencana-rencana pembuatan UU melalui Program Legislasi Nasional (Prolegnas), sebagaimana disebut dalam Pasal 15 UU Nomor 10 Tahun 2004, yang sudah diubah dengan UU Nomor 12 Tahun 2011 tentang Pembentukan Peraturan Perundangundangan. Melalui UU ini, untuk pertama kalinya disusun Prolegnas jangka menengah (2005-2009) yang menetapkan 284 RUU, melalui Kep.DPR No.01/DPR-RI/20042005. UU tersebut menjadi titik awal kemajuan dalam bidang politik hukum nasional karena UU tersebut dipandang sebagai instrumen perencanaan dan pembentukan UU yang disusun bersama, terpadu, sistematis. Bahkan ditentukan secara tegas agar RUU mengandung unsur kajian akademik dan partisipasi masyarakat sebagai wujud partisipasi politik, yang mana unsurunsurtersebut belum pernah terjadi sebelumnya, UU kerap kali dibuat tanpa perencanaan sistematis, (dengan cara-cara

21. Bagir Manan \& Dwi Harijanti, Op.cit, hlm.17.

22.Moh.Mahfud MD, 1999, Amandemen Konstitusi Menuju Reformasi Hukum Tata Negara, Yogyakarta, UII Press, hlm. 49. 
spontan) tiba-tiba diberlakukan di masyarakat. ${ }^{23}$ Inilah yang dinamakan kesemrawutan perencanaan pembuat UU pada zamannya itu.

Naskah akademik sebagaimana disebutkan di atas adalah kumpulan serangkaian masalah yang sudah, sedang dan akan terjadi di dalam masyarakat yang kemudian dikaji dari sudut pandang ilmiah akademik. Materi yang dikaji tersebut mencakup konsep pemikiran para pakar ilmu pengetahuan hukum, landasan filosofis dan landasan sosial serta landasan yuridis perihal perlunya UU tersebut diterbitkan.

Namun, kajian naskah akademik belum menjamin bahwa materi-materinya memenuhi syarat sebagai naskah berkualitas untuk menghasilkan suatu UU yang berkualitas pula. Problemnya adalah naskah akademik dan naskah partisipasi masyarakat tidak diatur dalam UU untuk mewajibkan naskah-naskah tersebut dimasukan ke dalam RUU. Kerap kali naskah akademik hanya menjadi bahan diskusi di panitia kerja (panja) dan lenyap ketika RUU disahkan pada sidang paripurna DPR. Problem tersebut berkaitan erat dengan keterbatasan SDM anggota DPR dan hal itu menjadi kegelisahan bagi Pataniari ${ }^{24}$ Dia mengatakan, bahwa kewenangan konstitusi DPR belum dimaksimalkan karena benturan SDM yang tersedia kurang memadai dan bahkan tidak memenuhi standar di dalam mengimplementasikan Program Legislasi Nasional tersebut.

Masalah SDM tersebut selalu menjadi obyek wacana publik, karena berkualitas atau tidaknya Prolegnas tergantung pada integritas diri anggota legislatif, yang mana kualitas SDM menjadi bagian di dalamnya. Tidaklah heran, jika beberapa UU yang normanya dibatalkan oleh Mahkamah Konstitusi. Bahkan rakyat biasa mampu menilai kualitas UU yang dibatalkan oleh MK, sehingga publik menghendaki agar proses pembahasan RUU harus melibatkan MK. Kegelisahan seperti itu akan berkurang jika politik hukum Prolegnas wajib menerima naskah akademik yang berkualitas dan anggota parlemen memiliki kualitas SDM yang memadai. Persoalan ini terkait langsung dengan proses pengkaderan anggota di lingkungan partai politik. Agar persoalan ini mendapat perhatian serius dari partai politik pengusung, anggota DPR wajib diakreditasi kemampuan dan wawasan kebangsaaannya oleh Lembaga Pertahanan Nasional (Lemhanas).

Implikasi perubahan UUD 1945, juga membias kepada penggabungan dua tradisi hukum, "rechtstaat" dan "rule of law". "Rechstaat" melahirkan legisme yang berkarakter hukum tertulis. Sedangkan "rule of law" berbasis pada keyakinan hakim dan praktek ketatanegaraan atau disebut konvensi. "Rule of law" lebih berbasis pada keadilan substantif yang tidak tergantung sepenuhnya pada konsep keadilan yang tertulis dalam pasal-pasal UU. Konsep "rule of law" ini sangat jelas digariskan oleh pasal 1 ayat (3) UUD Negara Republik Indonesia Tahun 1945. Dengan demikian setelah UUD mengalami perubahan, Indonesia menganut tradisi hukum legisme yang berbasis pada ketentuan yang tertulis dalam UU dan juga tradisi common law yang berbasis pada keyakinan hakim yang terwujud di dalam keputusan-keputusan Pengadilan yang biasa disebut sebagai pelaksanaan hukum dalam "in concreto."

Penggabungan dua tradisi hukum yaitu "legisme" dan "common law," akan menciptakan cita-cita hokum "prismatik." Kenyataan ini menempatkan lembaga pengadilan sebagai institusi yang penting dan strategis sehingga perlu diisi oleh mereka yang berkualitas dan berintegritas. Kasuskasus hukum yang melibatkan kedua lembaga (Kehakiman dan DPR) akhir-akhir ini menyebabkan hilangnya kredibilitas rakyat kepada lembaga tersebut. Padahal citacita hukum prismatic berorientasi pada penciptaan lembaga yang sungguh menjadi cermin tegaknya hukum dan sumber penemuan dan penciptaan hokum untuk ${ }_{25}$ pembangunan hukum nasional yang progresif dan sesuai dengan kebutuhan dan tuntutan riil

23.Moh. Kusnadi dan Harmaily Ibrahim, 1981, Pengantar Hukum Tata Negara, Jakarta, Pusat Studi HTN FH UI dan CV Sinar Bakti, hlm 20

24. Ibid, hlm. 430 .

25.Moh.Mahfud MD dkk, 2013, "Dekonstruksi dan Gerakan Pemikiran Hukum Progresif”, Konsorsium Hukum Progresif, Universitas Diponegoro Semarang, Yogyakarta, Thafa Media, hlm. 11. 
masyarakat masa kini dan masa depan. Sehubungan dengan itu, fungsi negara adalah menjaga keseimbangan antara prinsip-prinsip umum hukum, cita-cita hukum negara, falsafah Negara dan tujuan globalisasi. Kalau keseimbangan ini tidak terbangun maka hukum internasional akan memberikan pengaruh dan tekanan kepada bangsa Indonesia dan jika hal itu terjadi maka bangsa Indonesia terjajah kembali. Karena itu, diperlukan paradigma baru dalam cara berpikir tentang hukum sebagai sistem pengelolaan kehidupan berbangsa dan bernegara.

Sebagaimana sebelumnya telah dikemukakan bahwa politik hukum adalah suatu legal policy atau arah hukum yang akan diberlakukan negara untuk mencapai tujuannya dengan membentuk hukum baru dan menggantikan hukum lama, sehingga arah politik hukum Indonesia yang dicitacitakan tergambar dalam pohon hukum ilmiah Indonesia. ${ }^{27}$ Pohon ilmiah hukum tersebut mengandung unsur-unsur yaitu akar ilmu hukum adalah Falsafah Pancasila dan Pembukaan UUD 1945. Keduanya sebagai fondasi dan kaidah penuntun. Fondasi ilmiah itu disebut juga "principii in principii" (prinsipnya prinsip) dan "Principii in Actiones" (Prinsip Pelaksanaannya/Prinsip Politik) ${ }^{29}$, di dalam pembuatan produk perundang-undangan. Falsafah Pancasila sebagai landasan dalam upaya mendalami studi ilmu hukum dan pembukaan UUD 1945 sebagai landasan politik hukum, keduanya berada dalam batang pohon ilmiah tersebut. Dalam bingkai pendidikan politik hukum pada masa yang akan datang menuju citacita hukum atau kerangka keyakinan, sebaiknya berpijak pada pohon ilmiah hukum Pancasila untuk mencapai tujuan negara yaitu (a) melindungi semua unsur-unsur bangsa demi keutuhan bangsa, (b) mewujudkan keadilan sosial dalam bidang ekonomi dan kemasyarakatan, (c) mewujudkan kedaulatan rakyat (demokrasi) dan nomokrasi (negara hukum) dan (d) menetapkan toleransi atas dasar kemanusiaan dan keadaban dalam hidup beragama.

\section{Simpulan}

Politik hukum suatu negara menghasilkan Konstitusi, sedangkan produkproduk legislasi adalah hasil produk politik hukum tersebut. Mengetahui politik hukum dan falsafah suatu negara serta tujuan negara, dapat dipahami melalui konstitusi negara tersebut. Politik hukum merupakan instrumen pendorong bagi semua unsur sistem hukum nasional, sehingga bertugas sesuai dengan tujuan negara, cita-cita bangsa, cita-cita hukum dan kaidah penuntun yang terkandung dalam Pembukaan UUD 1945. Konstitusi dapat dimaknai sebagai "moral reading" yang mengandung kaidah dan pesan-pesan moral. Dengan itu konstitusi tidak lagi dipahami sebatas sebagai dokumen hukum, melainkan juga sebagai sesuatu yang bersifat "metayuris" yaitu suatu piagam pernyataan kemanusiaan, pernyataan ekspresi kosmologi bangsa, cita-cita bangsa dan landasan tujuan kemana negara itu dibawa. Setelah perubahan UUD 1945, Indonesia menganut negara hukum yang berimplikasi pada kebijakan untuk menerima kombinasi "tradisi legisme" dan tradisi "common law" dalam sistem hokum pada masa akan datang (constituendum). Kesediaan menerima kombinasi dua tradisi tersebut berdampak pada kebijakan penguatan DPR dan lembaga Yudikatif melalui penyediaan SDM yang memadai. Politik hukum Indonesia yang dicita-citakan ("iusconstituendum") tergambar dalam pohon hukum ilmiah Indonesia yang mengandung Falsafah Pancasila sebagai akar ilmu hukum atau filsafat ilmu hukumnya, sedangkan Pembukaan UUD 1945 sebagai landasan politik hukum. Keduanya berada dalam satu pohon cita-cita hukum yaitu pohon ilmiah hukum Pancasila. Perlu dilakukan kompromi politik di DPR untuk menyepakati Konvensi Ketatanegaraan atau Konvensi kebangsaan untuk menetapkan

\footnotetext{
26. Sunaryati Hartono, dalam Mahfud MD dkk, Op.cit, hlm 18

27. Moh.Mahfud MD, Kuliah Politik Hukum, Jakarta, Kampus UKI, 8 Nopember 2014

28. Ibid.

29. St Munadjat, 1987, Bunga Rampai Hukum Dan Lingkungan, Jakarta, Bina Cipta, hlm 45-46

30. Moh. Mahfud MD, Op.cit, hlm 18.
} 
Pancasila sebagai Pohon Ilmiah Hukum Nasional. Landasan filsafat ilmu hukum nasional berbasis pada falsafah Pancasila, sedangkan Politik Hukum Nasional berakar dan berbasis pada Pembukaan UUD 1945, alinea IV sebagai norma dasar.

\section{Daftar Pustaka}

Assiddiqie Jimlly, 2006, Pengantar Ilmu Hukum Tata Negara, Jilid I, Jakarta, Konstitusi Press, hlm 121122

Budiardjo Miriam, 2008, Dasar-Dasar Ilmu Politik, Edisi Revisi, Jakarta: Gramedia Pustaka Utama.

Campbell Black Henry, M.A., 1975, Black's Law Dictionary, Fourth Edition, Washington DC, The Pbulisher's Editorial Staff

Djatiman Sardjono, Kuliah Sosiologi Hukum, Pasca Sarjana UNKRIS, September 1999 ,

Djauhari, "Konsep Negara Kesejahteraan Pra Kemerdekaan RI”, Jurnal Hukum FH Unissula, Semarang, Vol. 16, No. 2, Juni 2006

Kusnadi Moh. dan Harmaily Ibrahim, 1981, Pengantar Hukum Tata Negara, Jakarta, Pusat Studi HTN FH UI dan CV Sinar Bakti

Lubis Solly, 1978, Asas-asas Hukum Tata Negara, Cet.ke-2, Bandung, Alumni Bandung.

Manan Bagir \& Harijanti, Dwi Susi, 2014, Memahami Konstitusi Makna dan Aktualisasi, Cet. Ke-1, Jakarta, PT.Raja Grafindo Persada.

Mahfud MD Moh, 2012, Pengantar Buku, Pataniara Siahaan, Politik Hukum Pembentukan UU Pasca Amandemen UUD 1945, Jakarta, Konpress

Mahfud MD Moh, 2010, Politik Hukum di Indonesia, Jakarta, PT. Raja Grafindo Persada.

Mahfud MD Moh dkk, 2013, "Dekonstruksi dan Gerakan Pemikiran Hukum Progresif", Konsorsium Hukum Progresif, Universitas Diponegoro Semarang, Yogyakarta, Thafa Media.
Mahfud MD Moh., 1999, Amandemen Konstitusi Menuju Reformasi Hukum Tata Negara, Yogyakarta, UII Press.

Mahfud MD Moh, Kuliah Politik Hukum, Jakarta, Kampus UKI, 8 Nopember 2014.

Munadjat St, 1987, Bunga Rampai Hukum Dan Lingkungan, Jakarta, Bina Cipta.

Numa Ndulo, 12 Januari 2011, Term Of.Reference Forum Group Discussion Re-Amandement, Bandung, Konstitusi Nasional -Demokrat PSKN FH Unpad

Pigome Martha, "Implementasi Prinsip Demokrasi dan Nomokrasi dalam Struktur Ketatanegaraan RI Pasca Amandemen UUD 1945", Jurnal Dinamika Hukum, Vol 11, No. 2, Mei 2011

Rahardjo Satjipto, 2007, Mendudukan Undang-Undang Dasar, Suatu Pembahasan dari Optik Ilmu Hukum Umum, Cet. I, Semarang, Badan penerbit Universitas Diponegoro.

Saleh Mr. Roeslan, Materi Kuliah Sejarah Hukum Indonesia, Pasca Sarjana UNKRIS, 1999. 